Article

\title{
Impacts of Trace Element Addition on Lentil (Lens culinaris L.) Agronomy
}

\author{
Md. Moshiul Islam ${ }^{1}$ * , Md. Razaul Karim ${ }^{1}$, Md. Moinul Hosain Oliver ${ }^{2}$, Tahmina Akter Urmi ${ }^{3}$, \\ Md. Ashraf Hossain ${ }^{4}$ and M. Moynul Haque ${ }^{1}$ \\ 1 Department of Agronomy, Bangabandhu Sheikh Mujibur Rahman Agricultural University, \\ Gazipur P.O. Box 1706, Bangladesh; razaul.pstu@gmail.com (M.R.K.); moynul60@yahoo.com (M.M.H.) \\ 2 Department of Agricultural Engineering, Bangabandhu Sheikh Mujibur Rahman Agricultural University, \\ Gazipur P.O. Box 1706, Bangladesh; oliver@bsmrau.edu.bd \\ 3 Department of Soil Science, Bangabandhu Sheikh Mujibur Rahman Agricultural University, \\ Gazipur P.O. Box 1706, Bangladesh; urmi.bsmrau@gmail.com \\ 4 Department of Soil Science, Bangladesh Agricultural Research Institute, Gazipur P.O. Box 1701, Bangladesh; \\ ashrafbdprc@gmail.com \\ * Correspondence: moshiul@bsmrau.edu.bd; Tel.: +88-0171-213-2019
}

Received: 27 May 2018; Accepted: 14 June 2018; Published: 27 June 2018

\begin{abstract}
Adequate supply of micronutrients is important for the proper growth and yield of lentil, particularly in poorly fertile soil. This study was carried out to understand the effects of zinc ( $\mathrm{Zn})$, boron (B), and molybdenum (Mo) on the growth and yield of lentil, and how these elements can help manage soil fertility issues. In this regard, the morpho-physiological traits of lentils (BARI Masur-7) were collected from two experiments receiving the same treatments carried out during consecutive rabi seasons of 2015-2016 and 2016-2017. The experiments were laid out with a randomized complete block design having eight treatments, and was replicated thrice. The treatments were $\mathrm{T}_{1}$ (Control), $\mathrm{T}_{2}\left(\mathrm{Zn}_{2.0} \mathrm{~kg} \mathrm{ha}^{-1}\right), \mathrm{T}_{3}\left(\mathrm{~B}_{1.5} \mathrm{~kg} \mathrm{ha}^{-1}\right), \mathrm{T}_{4}\left(\mathrm{Mo}_{1.0} \mathrm{~kg} \mathrm{ha}^{-1}\right), \mathrm{T}_{5}\left(\mathrm{Zn}_{2.0} \mathrm{~B}_{1.5} \mathrm{~kg} \mathrm{ha}^{-1}\right)$, $\mathrm{T}_{6}\left(\mathrm{Zn}_{2.0} \mathrm{Mo}_{1.0} \mathrm{~kg} \mathrm{ha}^{-1}\right), \mathrm{T}_{7}\left(\mathrm{~B}_{1.5} \mathrm{Mo}_{1.0} \mathrm{~kg} \mathrm{ha}^{-1}\right)$, and $\mathrm{T}_{8}\left(\mathrm{Zn}_{2.0} \mathrm{~B}_{1.5} \mathrm{Mo}_{1.0} \mathrm{~kg} \mathrm{ha}^{-1}\right)$. The results revealed that the application of micronutrients either singly or in combination had significant effects on the plant height, number of branches per plant, number of pods per plant, number of seeds per pod, thousand seed weight, and the seed yield of lentil. The maximum seed production was, however, observed in plots receiving treatment $\mathrm{T}_{8}$, i.e., the combined application of $\mathrm{Zn}, \mathrm{B}$, and Mo. Agronomic biofortification also had significantly increased protein content of lentil seeds while affecting the macro and micronutrient content of lentil seed. These results suggest that any micronutrient deficiencies might lead to a yield loss of lentil, and such a scenario could be avoided by a combined application of micronutrients at a proportionate level.
\end{abstract}

Keywords: micronutrients; lentil; crop characteristics; yield component; seed quality; soil properties

\section{Introduction}

Lentil (Lens culinaris L.) is an edible pulse that belongs to the family Fabaceae. Humans have known lentils since the beginning of civilization. It is one of the popular pulse crops in Bangladesh. Lentil seed contains $25 \%$ protein, $1.1 \%$ fat, $59 \%$ carbohydrate, and is also rich in important vitamins, minerals, and soluble and insoluble dietary fiber [1]. Due to the overpopulation of the country, the majority of fertile agricultural lands are occupied with cereal crops. This is why pulse crops are grown in marginal and poorly fertile soils under rain-fed conditions in Bangladesh. One of the major constraints of pulses production is the lack of proper management practices that has caused the continuous depletion of micronutrients due to intensive crop cultivation [2]. Therefore, the introduction 
of proper management practices, i.e., balancing the supply of macro and micronutrients, may play a major role in increasing the production of lentil.

Lentil production is largely influenced by the genotypic potential and the resistance to biotic and abiotic stresses [3]. However, among various edaphic factors, the availability of adequate plant nutrients is of prime importance. In particular, micronutrients were reported to have influenced the growth and yield of lentil [4,5]. Micronutrients contribute substantially to the achievement of higher production by influencing the symbiotic nitrogen-fixing process, where micronutrient deficiencies can limit nitrogen fixation by legume-rhizobium symbiosis and influence the effective uptake of different plant nutrients. Zinc (Zn), for instance, plays an important role in the biosynthesis of plant hormones, mainly indole acetic acid [6]. Many other enzymes such as the alcohol dehydrogenase (EC 1.1.1.1), superoxide dismutase (EC 1.15.1.1), carbonic anhydrase (EC 4.2.1.1), and RNA polymerase (EC 2.7.7.6) include zinc as a cofactor. It is, therefore, evident that zinc deficiency may inhibit protein synthesis in plant. Zn deficiency also reduces the water uptake by plants, affecting water use efficiency [7], nodulation, and nitrogen fixation [8]. In addition, $\mathrm{Zn}$ uptake is positively correlated with organic matter content in soil [8,9]. Sandy soils with less organic matter produce lower yields due to the poor utilization of $\mathrm{Zn}[10]$.

Boron (B) is one of the most import trace elements essential for plants. Boron can influence the absorption of $\mathrm{N}, \mathrm{P}$, and $\mathrm{K}$, and its deficiency can change the optimal equilibrium of those three macronutrients. Boron also plays a key role in sugar translocation, nitrogen fixation, protein synthesis, sucrose synthesis, cell wall composition, membrane stability, and $\mathrm{K}^{+}$transport [11]. Boron deficiency leads to sterility in plants by the malformation of reproductive tissues affecting pollen germination, and resulting in increased flower drop and reduced fruit set [12]. The other important micronutrient essential for the proper function of nitrogenase enzyme of Rhizobium bacteria is Molybdenum (Mo). It is also the cofactor for the nitrate reductase enzyme that is involved in nitrogen assimilation [13]. Molybdenum, being a constituent of nitrate reductase and nitrogenase enzymes, is associated with ammonia reduction and nitrogen fixation, and its deficiency adversely affects the growth and yield of crops [11]. In Mo-deficient crops, the flowers produced are fewer in number, smaller in size, and many of them fail to open or to mature, leading to lower seed yield [8].

It is reported in the scientific community that the application of micronutrients increases nodule formation, micronutrient uptake, and postharvest soil properties $[5,14,15]$. Several researchers have also reported that the conjunctive use of different micro and macronutrients significantly increases seed yield by $55-60 \%$, of which $20-25 \%$ could be ascribed to the micronutrients $[4,14,15]$. Valenciano et al. [16] found that $\mathrm{Zn}$ application was more efficient in chickpea when it was applied in conjunction with boron and molybdenum. Quddus et al. [17] reported that many soils of Bangladesh are deficient in zinc ( $\mathrm{Zn})$, boron (B), and molybdenum (Mo), which causes poor crop yields. The beneficial effects of these three micronutrients on groundnut, soybean, chickpea, and mungbean have already been reported in Bangladesh. However, their effect on lentil production is yet to be fully understood. The present study was therefore undertaken to evaluate the effects of micronutrients on seed yield, nutrient uptake, and the postharvest soil nutrient status of lentil field.

\section{Materials and Methods}

\subsection{Experimental Site and Soil}

The field experiment was conducted at the research field of the Pulses Research Sub-Station, Bangladesh Agricultural Research Institute (BARI), Gazipur, Bangladesh, during the winter season (November to February) of 2015-2016 and 2016-2017. The site is located at $24^{\circ} 0 / \mathrm{N}$ latitude and $90^{\circ} 25 / \mathrm{E}$ longitude at an elevation of $8.4 \mathrm{~m}$ above sea level. The soil of the study area belongs to the chhiata series under the agroecological zone (AEZ) Madhupur Tract (AEZ-28). The experimental site has a subtropical humid monsoon climatic condition. It is characterized by comparatively high monsoon rainfall, high humidity, and high temperature, long days with less clear sunshine, and sometimes the 
sky remains cloudy for heavy rainfall during the period from April to September. Scanty rainfall, low humidity, low temperature, short days, and more clear sunshine characterize the period from October to March. The average temperature ranges from $15.0-36.1^{\circ} \mathrm{C}$ and average annual rainfall varies from 1500-2200 mm around the year. Initial soil samples (0-15 cm depth) were collected from different spots of the experimental field and the characteristics of the experimental soil are given in Table 1.

Table 1. Physical and chemical properties of the soil used in the experiments.

\begin{tabular}{|c|c|}
\hline Soil Properties & Value \\
\hline Sand \% & 26.28 \\
\hline Silt \% & 38.20 \\
\hline Clay \% & 35.52 \\
\hline Textural class $(0-15 \mathrm{~cm})$ & Clay loam \\
\hline Particle density $\left(\mathrm{g} \mathrm{cm}^{-3}\right)$ & 2.51 \\
\hline Bulk density $\left(\mathrm{g} \mathrm{cm}^{-3}\right)$ & 1.35 \\
\hline Porosity (\%) & 46.22 \\
\hline $\mathrm{pH}$ & 6.6 \\
\hline Exchangeable K (meq. $100 \mathrm{~g}^{-1}$ ) & 0.11 \\
\hline Exchangeable $\mathrm{Ca}$ (meq. $100 \mathrm{~g}^{-1}$ ) & 6.01 \\
\hline Exchangeable $\mathrm{Mg}$ (meq. $100 \mathrm{~g}^{-1}$ ) & 2.02 \\
\hline Organic matter $(\%)$ & 1.28 \\
\hline Total N (\%) & 0.057 \\
\hline Available $\mathrm{P}\left(\mu \mathrm{g} \mathrm{g}^{-1}\right)$ & 23.5 \\
\hline Available $S\left(\mu \mathrm{g} \mathrm{g}^{-1}\right)$ & 26.0 \\
\hline Available $\mathrm{Zn}\left(\mu \mathrm{g} \mathrm{g}^{-1}\right)$ & 1.31 \\
\hline Available B $\left(\mu \mathrm{g} \mathrm{g}^{-1}\right)$ & 0.16 \\
\hline Available Mo $\left(\mu \mathrm{g} \mathrm{g}^{-1}\right)$ & 0.072 \\
\hline
\end{tabular}

\subsection{Experimental Design and Treatments}

The experiment was laid out in a randomized complete block design (RCBD) with eight treatments and three replications. The plot size was $4 \mathrm{~m} \times 3 \mathrm{~m}$. The treatments were $\mathrm{T}_{1}$ (Control), $\mathrm{T}_{2}\left(\mathrm{Zn}_{2.0} \mathrm{~kg} \mathrm{ha}^{-1}\right), \mathrm{T}_{3}\left(\mathrm{~B}_{1.5} \mathrm{~kg} \mathrm{ha}^{-1}\right), \mathrm{T}_{4}\left(\mathrm{Mo}_{1.0} \mathrm{~kg} \mathrm{ha}^{-1}\right), \mathrm{T}_{5}\left(\mathrm{Zn}_{2.0} \mathrm{~B}_{1.5} \mathrm{~kg} \mathrm{ha}^{-1}\right), \mathrm{T}_{6}\left(\mathrm{Zn}_{2.0} \mathrm{Mo}_{1.0} \mathrm{~kg} \mathrm{ha}^{-1}\right)$, $\mathrm{T}_{7}\left(\mathrm{~B}_{1.5} \mathrm{Mo}_{1.0} \mathrm{~kg} \mathrm{ha}^{-1}\right)$, and $\mathrm{T}_{8}\left(\mathrm{Zn}_{2.0} \mathrm{~B}_{1.5} \mathrm{Mo}_{1.0} \mathrm{~kg} \mathrm{ha}^{-1}\right)$. Basal application of fertilizer was made with $15 \mathrm{~kg}$ nitrogen $(\mathrm{N}), 20 \mathrm{~kg}$ phosphorus $(\mathrm{P}), 30 \mathrm{~kg}$ potassium $(\mathrm{K})$, and $10 \mathrm{~kg}$ sulfur $(\mathrm{S}) \mathrm{ha}^{-1}$ in all plots. Fertilizers of each treatment were applied to their respective plots at the final land preparation. The sources of N, P, K, S, zinc (Zn), boron (B), and molybdenum (Mo) were urea, triple super phosphate (TSP), muriate of potash (MoP), gypsum, zinc sulfate, boric acid, and sodium molybdate, respectively. Disease-free vigorous lentil (BARI Masur-7) seeds were sown on 8 November 2015 and 2016 with the spacing of $30 \mathrm{~cm} \times 5 \mathrm{~cm}$. The seed rate was $30 \mathrm{~kg} \mathrm{ha}^{-1}$. Standard crop management practices were employed. No pests and diseases were observed during the experimental period. Crops were harvested at maturity. Data on yield contributing characters were recorded from 10 randomly selected plants from each plot. The seed yield $\left(\mathrm{kg} \mathrm{ha}^{-1}\right)$ was recorded by the whole plot technique. The seed yield was adjusted to $10 \%$ moisture level [18]. The adjusted seed yield at 10\% moisture level per plot was converted to seed yield as kilogram per hectare.

\subsection{Protein Percentage}

The protein percentage in lentil seed was calculated considering the pulses food factor 5.30 [19]. The protein content was measured by multiplying the $\% \mathrm{~N}$ content of seed with the pulses food factor $5.30(\% \mathrm{~N} \times 5.30)$.

\subsection{Chemical Analysis of Plant Samples}

The collected grain and straw were air-dried in ambient conditions and then oven-dried at $65-70{ }^{\circ} \mathrm{C}$ for $72 \mathrm{~h}$. The dried samples were finely ground by using a Wiley-Mill with stainless contact 
points to pass through a 60-mesh sieve. Ground plant samples were digested with di-acid mixture $\left(\mathrm{HNO}_{3} \mathrm{HClO}_{4}\right)(5: 1)$ as described by Piper (1966) [20] for phosphorus (P), potassium (K), sulfur (S), zinc ( $\mathrm{Zn})$, and boron (B). Total nitrogen was determined using Kjeldhal systems [21]. Phosphorus was determined colorimetrically using the venadomolybdate blue ascorbic acid method by double beam spectrophotometry (Model no. 200-20, Hitachi, Tokyo, Japan) [22]. Potassium and zinc concentrations in the digest were directly measured by atomic absorption spectrophotometry (Model No.VARIAN SpectrAA 55B, Adelaide, Australia) and the sulfur concentration was determined by the turbidity method using $\mathrm{BaCl}_{2}$ by spectrophotometry [23]. The boron concentration was also determined by spectrophotometry following the azomethine-H method [23].

\subsection{Soil Analysis}

Soil samples were collected (up to $0-15 \mathrm{~cm}$ depth) at the initial stage and also after harvest from four different spots in each plot. The composite soil sample of each plot was brought to the laboratory for different soil analyses.

Particle size analysis of the soil was conducted using the hydrometer method [24]. The textural class was determined using Marshall's Triangular Coordinates of the USDA system.

Particle density was determined by the volumetric flask method [24] using the following formula:

$$
\text { Particle density }(\mathrm{Dp})=\frac{\mathrm{Ms}}{\mathrm{Vs}} \mathrm{g} \mathrm{cm}^{-3}
$$

where

$$
\begin{aligned}
& \mathrm{D}_{\mathrm{P}}=\text { Particle density }\left(\mathrm{g} \mathrm{cm}^{-3}\right) ; \\
& \text { Vs = Volume of soil solid }\left(\mathrm{cm}^{-3}\right) ; \\
& \text { Ms }=\text { Weight of soil solid }(\mathrm{g}) .
\end{aligned}
$$

Bulk density was determined by the core sampler method [24] using the following formula:

$$
\text { Bulk density }(\mathrm{Db})=\frac{\mathrm{Ms}}{\mathrm{Vt}} \mathrm{g} \mathrm{cm}^{-3}
$$

where

$$
\begin{aligned}
& \mathrm{Db}=\text { Bulk density }\left(\mathrm{g} \mathrm{cm}^{-3}\right) \\
& \mathrm{Ms}=\text { Mass of soil solid }(\mathrm{g}) ; \\
& \mathrm{Vt}=\text { Total volume of soil }\left(\mathrm{cm}^{-3}\right) .
\end{aligned}
$$

Soil porosity was calculated from the results of particle density and bulk density as:

$$
\text { Soil porosity }=\left(\frac{\mathrm{Dp}-\mathrm{Db}}{\mathrm{Dp}}\right) \times 100
$$

where

$$
\begin{aligned}
& \mathrm{Dp}=\text { Particle density }\left(\mathrm{g} \mathrm{cm}^{-3}\right) ; \\
& \mathrm{Db}=\text { Bulk density }\left(\mathrm{g} \mathrm{cm}^{-3}\right) .
\end{aligned}
$$

Soil $\mathrm{pH}$ was measured with the help of a glass electrode $\mathrm{pH}$ meter using a soil water suspension of 1:2.5 as described by Reference [23]. Organic carbon was determined following the wet oxidation method as described by Reference [23] and the organic matter content was calculated by multiplying the $\%$ organic carbon with the Van Bemmelen factor 1.73 [25]. Total nitrogen was determined using Kjeldhal systems [21]. Calcium and magnesium were determined by the ammonium acetate extraction method [26]. Phosphorus was determined colorimetrically using the venadomolybdate blue ascorbic acid method by double beam spectrophotometry (Model no. 200-20, Hitachi, Tokyo, Japan) [22]. Potassium and zinc concentrations in the digest were directly measured by atomic absorption 
spectrophotometry (Model No.VARIAN SpectrAA 55B, Australia) and the sulfur concentration was determined by the turbidity method using $\mathrm{BaCl}_{2}$ by spectrophotometry [23]. The boron concentration was also determined by spectrophotometry following the azomethine-H method [23].

\subsection{Statistical Analysis}

The collected data were analyzed to assess their statistical significance. Statistix 10 program was used to perform statistical analysis (www.statistix.com). Means were separated by the least significant difference (LSD) test at a 5\% level of significance [27].

\section{Results and Discussion}

\subsection{Effect of Micronutrients on Morpho-Physiological Characters of Lentil}

\subsubsection{Plant Height}

Plant height is the most important characteristic of the morpho-physiology which also acts as a key to shoot yield as well as total biomass production. Agronomic biofortification with Zn, B, and Mo significantly increased the plant height of lentil (Table 2). The highest plant height $(35.9 \mathrm{~cm})$ was recorded from the $T_{8}$ treatment which was statistically similar to $T_{5}$, and the lowest $(31.8 \mathrm{~cm})$ was recorded from the $\mathrm{T}_{1}$ (control) treatment (Table 2). As with other leguminous crops, Zn application resulted in more vegetative growth [28], leading to higher plant height. Different micronutrients might have helped in the synthesis of the auxin indole acetic acid and increased the plant height.

Table 2. Effect of Zn, B, and Mo applications on growth and yield characters of lentil. Averages from three independent experiments are shown (mean of 2 years of data).

\begin{tabular}{|c|c|c|c|c|c|c|c|}
\hline Treatments & $\begin{array}{c}\text { Plant } \\
\text { Height } \\
\text { (cm) }\end{array}$ & $\begin{array}{l}\text { Branches } \\
\text { Plant }^{-1}\end{array}$ & $\begin{array}{c}\text { Pods } \\
\text { Plant }^{-1}\end{array}$ & $\begin{array}{l}\text { Seeds } \\
\text { Pod }^{-1}\end{array}$ & $\begin{array}{l}1000 \\
\text { Seeds wt. } \\
(\mathrm{gm})\end{array}$ & $\begin{array}{c}\text { Seed } \\
\text { Yield } \\
\text { (Kg/ha) }\end{array}$ & $\begin{array}{c}\text { Seed } \\
\text { Protein } \\
(\%)\end{array}$ \\
\hline $\mathrm{T}_{1}=$ Control & $31.8 \mathrm{e}$ & $2.54 \mathrm{c}$ & $36.9 \mathrm{e}$ & $1.62 \mathrm{~d}$ & $17.3 \mathrm{c}$ & $822 \mathrm{~d}$ & $20.8 \mathrm{~b}$ \\
\hline $\mathrm{T}_{2}=\mathrm{Zn} 2.0 \mathrm{~kg} \mathrm{ha}^{-1}$ & $34.7 \mathrm{bc}$ & $2.74 \mathrm{~b}$ & $51.1 \mathrm{bcd}$ & $1.77 \mathrm{bc}$ & $18.7 \mathrm{~b}$ & $1081 \mathrm{bc}$ & $24.8 \mathrm{a}$ \\
\hline $\mathrm{T}_{3}=\mathrm{B} 1.5 \mathrm{~kg} \mathrm{ha}^{-1}$ & $34.1 \mathrm{~cd}$ & $2.76 \mathrm{~b}$ & $48.2 \mathrm{~cd}$ & $1.80 \mathrm{~b}$ & $18.6 \mathrm{~b}$ & 1066 c & $24.6 \mathrm{a}$ \\
\hline $\mathrm{T}_{4}=\operatorname{Mo} 1.0 \mathrm{~kg} \mathrm{ha}^{-1}$ & $33.5 \mathrm{~d}$ & $2.69 \mathrm{bc}$ & $48.0 \mathrm{~d}$ & $1.76 \mathrm{bc}$ & $18.3 \mathrm{~b}$ & 1015 c & $25.3 \mathrm{a}$ \\
\hline $\mathrm{T}_{5}=\mathrm{Zn}_{2.0} \mathrm{~B}_{1.5}$ & $35.1 \mathrm{ab}$ & $3.04 \mathrm{a}$ & $62.0 \mathrm{a}$ & $1.88 \mathrm{a}$ & $19.6 \mathrm{a}$ & $1203 a b$ & $25.2 \mathrm{a}$ \\
\hline $\mathrm{T}_{6}=\mathrm{Zn}_{2.0} \mathrm{Mo}_{1.0}$ & $34.9 \mathrm{bc}$ & $2.85 \mathrm{~b}$ & $52.9 \mathrm{~b}$ & $1.79 \mathrm{bc}$ & $18.4 \mathrm{~b}$ & $1105 \mathrm{bc}$ & $25.6 \mathrm{a}$ \\
\hline $\mathrm{T}_{7}=\mathrm{B}_{1.5} \mathrm{Mo}_{1.0}$ & $34.8 \mathrm{bc}$ & $2.84 \mathrm{~b}$ & $52.4 \mathrm{bc}$ & $1.78 \mathrm{bc}$ & $18.2 \mathrm{~b}$ & 1096 bc & $25.8 \mathrm{a}$ \\
\hline $\mathrm{T}_{8}=\mathrm{Zn}_{2.0} \mathrm{~B}_{1.5} \mathrm{Mo}_{1.0}$ & 35.9 a & $3.06 \mathrm{a}$ & $65.0 \mathrm{a}$ & $1.90 \mathrm{a}$ & $19.7 \mathrm{a}$ & $1256 \mathrm{a}$ & $26.7 \mathrm{a}$ \\
\hline $\mathrm{CV}(\%)$ & 1.70 & 3.33 & 4.72 & 1.46 & 1.55 & 6.61 & 6.71 \\
\hline LSD (0.05) & 1.04 & 0.164 & 4.29 & 0.046 & 0.504 & 1.27 & 2.92 \\
\hline
\end{tabular}

Values within a column having same letter(s) do not differ significantly $(p=0.05)$.

\subsubsection{Branches Plant ${ }^{-1}$}

Micronutrients have a significant effect on the number of branches per plant (Table 2). The maximum number of branches per plant (3.06) was recorded from the $\mathrm{T}_{8}$ treatment, which was statistically similar to the $\mathrm{T}_{5}$ treatment. The minimum (2.54) was recorded from the $\mathrm{T}_{1}$ (control) treatment, which was statistically similar to $\mathrm{T}_{4}$ (Table 2). A significant increase in number of branches per plant has been reported following the application of different micronutrients [29-32] and micronutrient mixtures [33] in different crops. 


\subsection{Effect of Micronutrients on Yield Components of Lentil}

\subsubsection{Number of Pods Plant ${ }^{-1}$}

The number of pods per plant is the most influential yield component, and is most closely correlated with seed yield. It is also the most variable component [34]. Data regarding pods per plant of lentil as influenced by different micronutrient applications is shown in Table 2. Analysis of the data revealed that the effect of the treatments was significant on the number of pods per plant. During the single application of $\mathrm{Zn}, \mathrm{B}$, and Mo, the highest number of pods per plant (51.1) was obtained from the $T_{2}$ treatment and the lowest (48.0) was obtained from the $T_{4}$ treatment (Table 2). However, among all of the treatments, the highest number of pods per plant (65.0) was recorded from the $\mathrm{T}_{8}$ treatment, which was statistically similar to the $T_{5}$ treatment, while the lowest (36.9) was recorded from the $\mathrm{T}_{1}$ (control) treatment (Table 2). The results indicate that micronutrients have a positive effect on the pod set of lentils. The pod set was increased by $76.15 \%$ in $\mathrm{T}_{8}$ over the control. This could be due to the greater role of micronutrients in the production of indole acetic acid (IAA), which may have resulted in more pods per plant [35]. Micronutrients also increase the number of branches due to the formation of stamens and pollens [36]. The enhancing effect of zinc, boron, and molybdenum on pods per plant has been reported in mungbean [37], chickpea [38], green gram [39], french bean [40], and cowpea [15]. The results of this study contribute to the growing body of knowledge about the effect of these micronutrients on lentils.

\subsubsection{Number of Seeds $\operatorname{Pod}^{-1}$}

The number of seeds per pod is the least variable yield component. It was also significantly influenced by agronomic biofortification (Table 2). The highest number of seeds per pod (1.90) was obtained from the $T_{8}$ treatment, which was statistically similar to the $T_{5}$ treatment, and the lowest (1.62) was recorded from the $\mathrm{T}_{1}$ (control) treatment (Table 2). Similar results have been reported in the case of mungbean [37] and green gram [39], showing the relevance of the present study, and inferring the fact that agronomic biofortification might have enhanced the seed setting that resulted in an increasing number of seeds per pod.

\subsubsection{Thousand Seed Weight}

Seed weight is an important quality attribute of crops. Although this character is genetically controlled, the growing condition also exerts considerable influence on its expression. In the present study, the thousand seed weight of lentils was significantly influenced by the application of Zn, B, and Mo. The highest thousand seed weight $(19.7 \mathrm{~g})$ was obtained from the $\mathrm{T}_{8}$ treatment, which was statistically similar to the $T_{5}$ treatment, and the lowest $\left(17.3 \mathrm{~g}\right.$ ) was obtained from the $T_{1}$ (control) treatment (Table 2). This could be due to the higher mobilization of photosynthates to the developing seeds in $\mathrm{T}_{8}$ caused by the agronomic biofortification of $\mathrm{Zn}, \mathrm{B}$, and Mo. The results of this study conform with the findings of a number of previous reports [37,39] for mungbean and green gram.

\subsubsection{Seed Yield}

Seed yield is an important consideration for any study relating to the commercial cultivation as well as the seed production of a crop. Seed yield depends on the number of pods per plant, seeds per pod, and seed weight. The results from Table 2 indicated that the application of micronutrients either singly or in combination had a significant effect on the seed yield of lentil. However, the maximum increase in seed yield was observed following the combined application of $\mathrm{Zn}, \mathrm{B}$, and Mo. All other treatments were found to have moderate to low effects in enhancing the seed yield of this crop. The increase in seed yield varied from 23.48 to $52.80 \%$ at different treatments compared to the controls (Table 2). This indicates the fact that agronomic biofortification may have fostered the photosynthesis process and translocation of photosynthetic products to the seed as a result of an 
increase in enzymatic activity. The plots lacking in one of the micronutrients $\left(T_{5}, T_{6}\right.$, and $T_{7}$ treatments) showed lower seed yield than $\mathrm{T}_{8}$ treatments where $\mathrm{Zn}, \mathrm{B}$, and Mo were applied in combination. On the other hand, when $\mathrm{Zn}, \mathrm{B}$, and Mo were applied individually to soil, the increase in seed yield was marginal but statistically different from the control. This result indicates that any micronutrient deficiencies may result in yield loss, and this could be recovered if the relevant micronutrients are applied. The best results would therefore be achieved if micronutrients are applied in conjunction with macronutrients to favorably influence the plant vigor, morphology, and metabolic processes. The results of this experiment are in agreement with the findings of a number of previous research endeavors involving other crops [38,40-43]. Yang et al. [44] for instance, reported that the combined application of B with Mo or $\mathrm{Zn}$ resulted in higher seed yield than the application of $\mathrm{B}$, Mo, or $\mathrm{Zn}$ alone, and the combined application of $\mathrm{B}, \mathrm{Mo}$, and $\mathrm{Zn}$ increased the seed yield by $68.1 \%$ compared to the controls.

\subsection{Effects of Micronutrients on the Protein Content of Lentil Seed}

Agronomic biofortification with Zn, B, and Mo had a significant effect on the seed protein content of lentil (Table 2). The highest seed protein content (26.7\%) was obtained from the $\mathrm{T}_{8}$ treatment, which was statistically similar to $\mathrm{T}_{7}(25.8 \%), \mathrm{T}_{6}(25.6 \%), \mathrm{T}_{5}(25.2 \%), \mathrm{T}_{4}(25.3 \%), \mathrm{T}_{3}(24.6 \%)$, and $\mathrm{T}_{2}(24.8 \%)$. The lowest $(20.8 \%)$ protein content, however, was obtained from the $\mathrm{T}_{1}$ (control) treatment (Table 2). It has been reported that the protein percentage in grain of moth bean (Vigna aconitifolia (Jacq.) Marechal) increased significantly following Mo application [45]. Barik and Rout [46] also observed that agronomic biofortification with Mo, Zn, B, K, and S enhanced the seed protein content of pulses. This is because an increase in micronutrient availability enhances $\mathrm{N}$ uptake by plants through nodule formation, which increases the protein content in seeds [47].

\subsection{Effects of Micronutrients on the Nodule Formation of Lentil}

The results of the consecutive experiments of this study show that the number of nodules per plant was gradually increased from 32 days after seeding (DAS) to 62 DAS, and then decreased regardless of treatment (Figure 1). The results also indicate that every micronutrient has an important role in nodule formation. The highest number of nodules per plant (58.5) was recorded for $\mathrm{T}_{8}$ after 62 days of sowing, which was statistically similar to $\mathrm{T}_{6}$, and the lowest number of nodules per plant (13.7) was recorded for $\mathrm{T}_{1}$ (control) at 32 DAS (Figure 1). From the results of different dates, we found that the lowest numbers of nodules per plant were recorded at 32 DAS and 77 DAS while the highest numbers of nodules per plant were recorded between 47 and 62 DAS. It seems that the highest number of nodules formation occurred during early to mid-flowering stages. After flowering, nodules formation efficiency was reduced. Micronutrients play important roles as constituents of organic structures, constituents or activators of enzymes, electron carriers, and in osmoregulation. Micronutrients may also influence $\mathrm{N}_{2}$ fixation in legumes and nonlegumes at various levels of the symbiotic interactions: infection and nodule development, nodule function, and host plant growth [48]. Bolanos et al. [49] studied the effect of boron on Rhizobium-legume cell-surface interaction and nodule development in pea. In boron-deficient plants, the number of Rhizobia infecting the host cells and the number of infection threads were found to have reduced. Moreover, the infection threads had developed morphological aberrations and reduced the nodule number. It has been reported that the Fe-Mo cofactor (FeMoco) of nitrogenase constitutes the active site of the molybdenum-containing nitrogenase protein in N2-fixing organisms [50]. Although at a low supply, molybdenum is an essential trace element and is vital for the synthesis and activity of molybdoenzymes such as nitrogen assimilation enzyme-nitrate reductase and the nitrogen-fixing enzyme-nitrogenase, the key regulatory component for the initiation of nodulation and the maintenance of nitrogen fixation in legumes [51]. The present results are in agreement with these previous studies that explained the reason for low nodule formulation at later stages in lentils. 


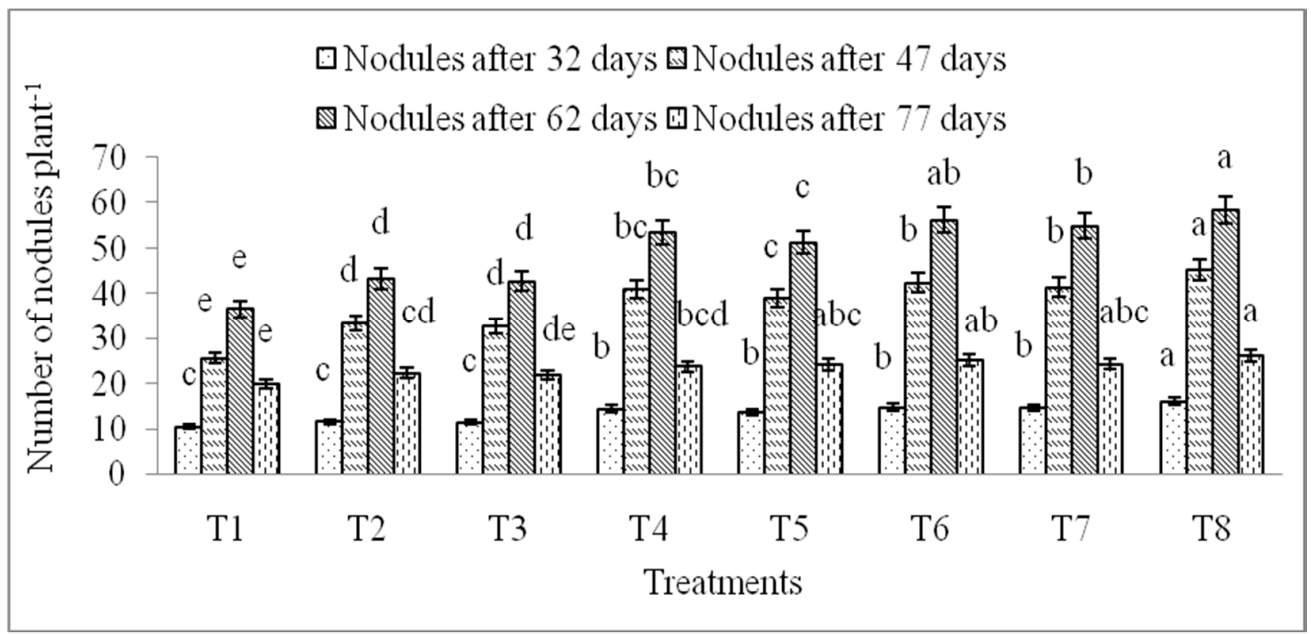

Figure 1. Effects of $\mathrm{Zn}, \mathrm{B}$, and Mo on number of nodules per plant of lentil at different days after seeding. Averages from three independent experiments are shown. Error bars represent the SEM. Means followed by uncommon letter(s) are significantly different from each other at the $5 \%$ level of significance. Note: $\mathrm{T}_{1}=$ Control, $\mathrm{T}_{2}=\mathrm{Zn} 2.0 \mathrm{~kg} \mathrm{ha}^{-1}, \mathrm{~T}_{3}=\mathrm{B} 1.5 \mathrm{~kg} \mathrm{ha}^{-1}, \mathrm{~T}_{4}=$ Mo $1.0 \mathrm{~kg} \mathrm{ha}^{-1}$, $\mathrm{T}_{5}=\mathrm{Zn}_{2.0} \mathrm{~B}_{1.5}, \mathrm{~T}_{6}=\mathrm{Zn}_{2.0} \mathrm{Mo}_{1.0}, \mathrm{~T}_{7}=\mathrm{B}_{1.5} \mathrm{Mo}_{1.0}, \mathrm{~T}_{8}=\mathrm{Zn}_{2.0} \mathrm{~B}_{1.5} \mathrm{Mo}_{1.0}$.

\subsection{Effects of Micronutrients on the $N, P, K, S, Z n$, and B Content of Lentil}

The uptake of N, P, K, S, Zn, and B by lentil (grain and straw) was markedly influenced by agronomic biofortification (Tables 3 and 4). The results showed that agronomic biofortification had a significant influence on the $\mathrm{N}$ content of lentil (seed and straw). The highest $\mathrm{N}$ content $(5.04 \%$ in seed and $1.74 \%$ in straw) was obtained from the $\mathrm{T}_{8}$ treatment, which was statistically similar to $\mathrm{T}_{7}(4.88 \%$ and $1.67 \%), \mathrm{T}_{6}(4.83 \%$ and $1.64 \%), \mathrm{T}_{5}(4.76 \%), \mathrm{T}_{4}(4.78 \%), \mathrm{T}_{3}(4.65 \%)$, and $\mathrm{T}_{2}(4.68 \%)$, while the lowest $\mathrm{N}$ content $\left(3.92 \%\right.$ in seed and $1.18 \%$ in straw) was obtained from the control ( $\mathrm{T}_{1}$ treatment) (Tables 3 and 4). It has been reported that the agronomic biofortification of grain legumes in field conditions increases $\mathrm{N}_{2}$ fixation and nodule mass, resulting in higher $\mathrm{N}$ content in grain $[52,53]$.

Table 3. Effect of Zn, B, and Mo applications on N, P, K, S, Zn, and B content in lentil seed. Averages from three independent experiments are shown (mean of 2 years of data).

\begin{tabular}{lcccccc}
\hline \multicolumn{1}{c}{ Treatments } & $\mathbf{N ~ ( \% )}$ & $\mathbf{P ~ ( \% )}$ & $\mathbf{K}(\%)$ & $\mathbf{S ~ ( \% )}$ & $\mathbf{Z n}\left(\boldsymbol{\mu g} \mathbf{g}^{-\mathbf{1}}\right)$ & $\left.\mathbf{B ~ ( \mu g ~ g}^{-\mathbf{1}}\right)$ \\
\hline $\mathrm{T}_{1}=$ Control & $3.92 \mathrm{~b}$ & $0.22 \mathrm{e}$ & $0.61 \mathrm{c}$ & $0.13 \mathrm{~d}$ & $59.0 \mathrm{~d}$ & $31.2 \mathrm{~d}$ \\
$\mathrm{~T}_{2}=\mathrm{Zn} 2.0 \mathrm{~kg} \mathrm{ha}^{-1}$ & $4.68 \mathrm{a}$ & $0.29 \mathrm{~cd}$ & $0.62 \mathrm{c}$ & $0.15 \mathrm{~cd}$ & $70.8 \mathrm{ab}$ & $32.3 \mathrm{~d}$ \\
$\mathrm{~T}_{3}=\mathrm{B} 1.5 \mathrm{~kg} \mathrm{ha}^{-1}$ & $4.65 \mathrm{a}$ & $0.30 \mathrm{bcd}$ & $0.69 \mathrm{bc}$ & $0.14 \mathrm{~d}$ & $65.6 \mathrm{c}$ & $37.5 \mathrm{c}$ \\
$\mathrm{T}_{4}=\mathrm{Mo} 1.0 \mathrm{~kg} \mathrm{ha}^{-1}$ & $4.78 \mathrm{a}$ & $0.28 \mathrm{~d}$ & $0.76 \mathrm{ab}$ & $0.17 \mathrm{~cd}$ & $67.5 \mathrm{bc}$ & $32.7 \mathrm{~d}$ \\
$\mathrm{~T}_{5}=\mathrm{Zn}_{2.0} \mathrm{~B}_{1.5}$ & $4.76 \mathrm{a}$ & $0.33 \mathrm{abc}$ & $0.79 \mathrm{ab}$ & $0.20 \mathrm{bc}$ & $70.0 \mathrm{abc}$ & $40.1 \mathrm{ab}$ \\
$\mathrm{T}_{6}=\mathrm{Zn}_{2.0} \mathrm{Mo}_{1.0}$ & $4.83 \mathrm{a}$ & $0.31 \mathrm{bcd}$ & $0.77 \mathrm{ab}$ & $0.23 \mathrm{~b}$ & $69.3 \mathrm{abc}$ & $38.7 \mathrm{bc}$ \\
$\mathrm{T}_{7}=\mathrm{B}_{1.5} \mathrm{Mo}_{1.0}$ & $4.88 \mathrm{a}$ & $0.34 \mathrm{ab}$ & $0.81 \mathrm{a}$ & $0.25 \mathrm{~b}$ & $68.1 \mathrm{abc}$ & $40.6 \mathrm{ab}$ \\
$\mathrm{T}_{8}=\mathrm{Zn}_{2.0} \mathrm{~B}_{1.5} \mathrm{Mo}_{1.0}$ & $5.04 \mathrm{a}$ & $0.36 \mathrm{a}$ & $0.86 \mathrm{a}$ & $0.34 \mathrm{a}$ & $72.4 \mathrm{a}$ & $41.5 \mathrm{a}$ \\
\hline $\mathrm{CV}(\%)$ & 6.79 & 9.14 & 7.84 & 10.2 & 3.83 & 3.25 \\
$\mathrm{LSD}(0.05)$ & 0.56 & 0.049 & 0.102 & 0.076 & 4.56 & 2.10 \\
\hline
\end{tabular}

Values within a column having same letter(s) do not differ significantly $(p=0.05)$.

Agronomic biofortification with $\mathrm{Zn}, \mathrm{B}$, and Mo had a significant effect on the $\mathrm{P}$ and $\mathrm{S}$ content in lentil (seed and straw). The highest amount of $\mathrm{P}(0.36 \%$ in seed and $0.18 \%$ in straw) was obtained from the $T_{8}$ treatment, which was statistically similar to $T_{7}$, and the highest amount of $S(0.34 \%$ in seed and $0.54 \%$ in straw) was obtained from the $\mathrm{T}_{8}$ treatment, which was not statistically similar to any other treatment. The lowest amount of both $\mathrm{P}$ and $\mathrm{S}$ was recorded from the $\mathrm{T}_{1}$ (control) treatment 
(Tables 3 and 4). Regarding K content, the highest $\mathrm{K}$ content in lentil seed $(0.86 \%)$ was obtained from the $\mathrm{T}_{8}$ treatment, which was statistically similar to $\mathrm{T}_{7}, \mathrm{~T}_{6}, \mathrm{~T}_{5}$, and $\mathrm{T}_{4}$. The highest $\mathrm{K}$ content in lentil straw $(0.72 \%)$ was also obtained from the $\mathrm{T}_{8}$ treatment, which was not statistically similar to any other treatment. On the other hand, the lowest K content (both in seed and straw) was found for the $\mathrm{T}_{1}$ (control) treatment (Table 3). The highest Zn content in lentil $\left(72.4 \mu \mathrm{g} \mathrm{g}^{-1}\right.$ in seed and $49.1 \mu \mathrm{g} \mathrm{g}^{-1}$ in straw) was obtained from the $\mathrm{T}_{8}$ treatment. which was statistically similar to $\mathrm{T}_{7}\left(68.1 \mu \mathrm{g} \mathrm{g}^{-1}\right.$ in seed and $48.5 \mu \mathrm{g} \mathrm{g}^{-1}$ in straw), $\mathrm{T}_{6}\left(69.3 \mu \mathrm{g} \mathrm{g}^{-1}\right)$. and $\mathrm{T}_{5}\left(70.0 \mu \mathrm{g} \mathrm{g}^{-1}\right)$. The lowest $\left(59.0 \mu \mathrm{g} \mathrm{g}^{-1}\right.$ in seed and $42.1 \mathrm{\mu g} \mathrm{g}^{-1}$ in straw) $\mathrm{Zn}$ content was. however, obtained from the control ( $\mathrm{T}_{1}$ treatment). The highest $\mathrm{B}$ content in lentil ( $41.5 \mu \mathrm{g} \mathrm{g}^{-1}$ in seed and $31.7 \mu \mathrm{g} \mathrm{g}^{-1}$ in straw) was recorded from the $\mathrm{T}_{8}$ treatment, which was statistically similar to $\mathrm{T}_{7}\left(40.6 \mu \mathrm{g} \mathrm{g}^{-1}\right.$ in seed) and $\mathrm{T}_{5}\left(40.1 \mu \mathrm{g} \mathrm{g}^{-1}\right.$ in seed). The lowest $\mathrm{Zn}$ and $B$ content (seed and straw) was obtained from control ( $T_{1}$ treatment) (Tables 3 and 4 ). Increases of the $\mathrm{Zn}$ and B content in both straw and seeds go along with $\mathrm{Zn}$ and B applications to the soil. Similar results have been reported in previous studies involving different crops, where micronutrients were shown to have influenced the uptake of N, P, K, S, Zn, and B [54-58].

Table 4. Effect of Zn, B, and Mo applications on N, P, K, S, Zn, and B content in lentil straw. Averages from three independent experiments are shown (mean of 2 years of data).

\begin{tabular}{|c|c|c|c|c|c|c|}
\hline Treatments & N (\%) & $P(\%)$ & $\mathrm{K}(\%)$ & S (\%) & $\mathrm{Zn}\left(\mu \mathrm{g} \mathrm{g}^{-1}\right)$ & $B\left(\mu g g^{-1}\right)$ \\
\hline $\mathrm{T}_{1}=$ Control & $1.18 \mathrm{e}$ & $0.12 \mathrm{e}$ & $0.59 \mathrm{e}$ & $0.45 \mathrm{e}$ & $42.1 \mathrm{~d}$ & $25.6 \mathrm{~d}$ \\
\hline $\mathrm{T}_{2}=\mathrm{Zn} 2.0 \mathrm{~kg} \mathrm{ha}^{-1}$ & $1.42 \mathrm{~d}$ & $0.17 \mathrm{a}$ & $0.63 \mathrm{~d}$ & $0.49 \mathrm{~d}$ & $48.2 \mathrm{ab}$ & $26.1 \mathrm{~d}$ \\
\hline $\mathrm{T}_{3}=\mathrm{B} 1.5 \mathrm{~kg} \mathrm{ha}^{-1}$ & $1.41 \mathrm{~d}$ & $0.16 \mathrm{ab}$ & $0.64 \mathrm{~d}$ & $0.50 \mathrm{~cd}$ & $43.3 \mathrm{~cd}$ & $28.1 \mathrm{c}$ \\
\hline $\mathrm{T}_{4}=\mathrm{Mo} 1.0 \mathrm{~kg} \mathrm{ha}^{-1}$ & $1.52 \mathrm{~cd}$ & $0.15 \mathrm{bc}$ & $0.65 \mathrm{~cd}$ & $0.48 \mathrm{~d}$ & $44.5 \mathrm{~cd}$ & $27.6 \mathrm{c}$ \\
\hline $\mathrm{T}_{5}=\mathrm{Zn}_{2.0} \mathrm{~B}_{1.5}$ & $1.59 \mathrm{bc}$ & $0.14 \mathrm{~cd}$ & $0.69 \mathrm{~b}$ & $0.52 \mathrm{~b}$ & $47.8 \mathrm{ab}$ & $30.0 \mathrm{~b}$ \\
\hline $\mathrm{T}_{6}=\mathrm{Zn}_{2.0} \mathrm{Mo}_{1.0}$ & $1.64 \mathrm{abc}$ & 0.13 de & $0.68 \mathrm{~b}$ & $0.51 \mathrm{bc}$ & $45.8 \mathrm{bc}$ & $28.0 \mathrm{c}$ \\
\hline $\mathrm{T}_{7}=\mathrm{B}_{1.5} \mathrm{Mo}_{1.0}$ & $1.67 \mathrm{ab}$ & $0.16 \mathrm{ab}$ & $0.67 \mathrm{bc}$ & $0.50 \mathrm{~cd}$ & $48.5 \mathrm{ab}$ & $29.2 \mathrm{~b}$ \\
\hline $\mathrm{T}_{8}=\mathrm{Zn}_{2.0} \mathrm{~B}_{1.5} \mathrm{Mo}_{1.0}$ & $1.74 \mathrm{a}$ & $0.18 \mathrm{a}$ & $0.72 \mathrm{a}$ & $0.54 \mathrm{a}$ & $49.1 \mathrm{a}$ & $31.7 \mathrm{a}$ \\
\hline $\mathrm{CV}(\%)$ & 4.62 & 6.17 & 2.56 & 1.90 & 3.48 & 1.93 \\
\hline LSD (0.05) & 0.123 & 0.016 & 0.030 & 0.017 & 2.82 & 0.960 \\
\hline
\end{tabular}

Values within a column having same letter(s) do not differ significantly $(p=0.05)$.

\subsection{Effects of Micronutrients on Postharvest Soil Properties}

The $\mathrm{pH}$ of postharvest soils slightly increased in all of the treatments (Table 5) after the 2 years of consecutive experiments. This was the result of the incorporation of lentil stover in soil. It has been reported that organic matter from crop residue increases the soil $\mathrm{pH}$ status by improving the soil buffering capacity [59]. Organic matter increases the cation exchange capacity, which contributes to a high base saturation of the soil. As the base saturation increases, the relative amount of cations neutralizes. Our results were supported by many other researchers [60-62], who reported an increase of soil $\mathrm{pH}$ resulting from increased organic matter. It was also reported that plants can alter soil $\mathrm{pH}$ by releasing root exudates, such as organic acid anions, to enhance mineral nutrient solubility, as well as by the liberation of $\mathrm{H}^{+}$and $\mathrm{OH}^{-}$(or $\mathrm{HCO}_{3}{ }^{-}$resulting from $\mathrm{OH}^{-}$carbonation) in order to counterbalance cations or anions entering the roots. The decomposition of organic acid anions can also foster proton consumption in the decarboxylation process, which may result in the increase of soil $\mathrm{pH}$, which explains the results of our study.

The results of this study suggest that the application of $\mathrm{Zn}, \mathrm{B}$, and Mo did not affect the macro and micronutrient content of the soil, nor did it affect the organic matter content (Table 5). Nonetheless, the highest amount of organic matter $(1.50 \%)$ was obtained from the $\mathrm{T}_{8}$ treatment and the lowest $(1.35 \%)$ was from the $\mathrm{T}_{1}$ treatment. In most of the cases, the highest macro and micronutrient content of the postharvest soil was recorded from the $T_{8}$ treatment and the lowest was from the $T_{1}$ treatment. The results also showed that agronomic biofortification with $\mathrm{Zn}, \mathrm{B}$, and Mo had a prominent effect on the availability of nutrients in the soil. It has been reported that the incorporation of pulses stover in soil after the picking of pods resulted in an economy of about $23 \mathrm{~kg} \mathrm{~N} /$ ha in the succeeding crop [63]. 
It was found that the pulses receiving optimum fertilizer had more pronounced residual effect both for macro and micronutrients in the succeeding crops $[64,65]$. Regardless of the treatments of this study, the consecutive experiments yielded similar results that may help the scientific community to better understand the dynamics of micronutrients in lentil production. Our results also shed lights on how such management practices can help increase the fertility status of poorly fertile soils.

Table 5. Effect of Zn, B, and Mo applications on postharvest soil $\mathrm{pH}$ and the status of different nutrients. Averages from three independent experiments are shown (mean of 2 years of data).

\begin{tabular}{|c|c|c|c|c|c|c|c|c|c|c|}
\hline \multirow{2}{*}{ Treatment } & \multirow{2}{*}{$\mathrm{pH}$} & \multirow{2}{*}{ OM (\%) } & \multirow{2}{*}{ Total N (\%) } & $\mathrm{Ca}$ & $\mathrm{Mg}$ & K & $\mathbf{P}$ & $S$ & $\mathrm{Zn}$ & B \\
\hline & & & & \multicolumn{3}{|c|}{ meq. $100 \mathrm{~g}^{-1}$} & \multicolumn{4}{|c|}{$\mu g^{-1}$} \\
\hline Initial & 6.61 & 1.28 & 0.057 & 6.01 & 2.02 & 0.11 & 23.5 & 26.0 & 1.31 & 0.16 \\
\hline Critical level & & & 0.12 & 2.0 & 0.80 & 0.20 & 10.0 & 10.0 & 0.60 & 0.2 \\
\hline $\mathrm{T}_{1}=\mathrm{Zn}_{0} \mathrm{~B}_{0} \mathrm{Mo}_{0}$ & 6.71 & 1.35 & 0.062 & 5.90 & 2.00 & 0.10 & 24.0 & 25.2 & 1.28 & 0.14 \\
\hline $\mathrm{T}_{2}=\mathrm{Zn}_{2.0}$ & 6.78 & 1.45 & 0.064 & 6.01 & 2.00 & 0.11 & 24.5 & 25.3 & 1.41 & 0.15 \\
\hline $\mathrm{T}_{3}=\mathrm{B}_{1.5}$ & 6.77 & 1.38 & 0.065 & 6.01 & 2.01 & 0.11 & 24.6 & 25.5 & 1.31 & 0.20 \\
\hline $\mathrm{T}_{4}=\mathrm{Mo}_{1.0}$ & 6.82 & 1.39 & 0.067 & 6.00 & 2.02 & 0.10 & 24.8 & 25.8 & 1.32 & 0.16 \\
\hline $\mathrm{T}_{5}=\mathrm{Zn}_{2.0} \mathrm{~B}_{1.5}$ & 6.93 & 1.47 & 0.069 & 5.89 & 2.00 & 0.11 & 24.6 & 25.7 & 1.43 & 0.23 \\
\hline $\mathrm{T}_{6}=\mathrm{Zn}_{2.0} \mathrm{Mo}_{1.0}$ & 6.93 & 1.47 & 0.068 & 5.91 & 2.01 & 0.10 & 24.7 & 25.6 & 1.44 & 0.17 \\
\hline $\mathrm{T}_{7}=\mathrm{B}_{1.5} \mathrm{Mo}_{1.0}$ & 6.96 & 1.49 & 0.070 & 5.92 & 2.02 & 0.10 & 24.6 & 25.7 & 1.36 & 0.26 \\
\hline \multirow[t]{2}{*}{$\mathrm{T}_{8}=\mathrm{Zn}_{2.0} \mathrm{~B}_{1.5} \mathrm{Mo}_{1.0}$} & 7.01 & 1.50 & 0.072 & 5.88 & 2.00 & 0.11 & 24.7 & 25.9 & 1.45 & 0.27 \\
\hline & NS & NS & NS & NS & NS & NS & NS & NS & NS & NS \\
\hline
\end{tabular}

NS: not significant.

\section{Conclusions}

This study was carried out to understand the role of $\mathrm{Zn}, \mathrm{B}$, and Mo in the production of lentils and how the application of these elements can help manage soil fertility issues. In this regard, the morpho-physiological traits of lentils were deduced from two experiments receiving the same treatments carried out during consecutive seasons in 2015-2016 and 2016-2017. The agronomic biofortification had influenced the plant height, branch per plant, and, importantly, the number of nodules per plant. Such an introduction of micronutrients was found to have triggered more pod setting and more seeds per pod, which ultimately enhanced the seed yield. The conjunctive use of $\mathrm{Zn}$, $\mathrm{B}$, and Mo also had a significant effect on the protein content of seeds. These promising results suggest that agronomic biofortification with Zn, B, and Mo may be recommended for a higher yield of lentil in marginal and poorly managed soils under rain-fed conditions.

Author Contributions: M.M.I., M.M.H. and M.A.H. conceived and designed the experiments; M.M.I., M.R.K. and T.A.U. performed the experiments; M.M.I., M.A.H., T.A.U. and M.R.K. analyzed the data; M.M.I. and M.A.H. contributed reagents/materials/analysis tools; M.M.I., M.R.K., M.M.H.O., T.A.U., M.A.H. and M.M.H. wrote the paper.

Funding: This research received no external funding.

Acknowledgments: The authors would like to thank the Bangladesh Agricultural Research Institute for their facilities, in which the experiment was conducted.

Conflicts of Interest: The authors declare no conflict of interest.

\section{References}

1. Faris, M.A.I.E.; Takruri, H.R.; Issa, A.Y. Role of lentils (Lens culinaris L.) in human health and nutrition: A review. Mediterr. J. Nutr. Metab. 2013, 6, 3-16. [CrossRef]

2. Fageria, N.K.; Baligar, C.; Clark, R.B. Micronutrients in crop production. Adv. Agron. 2002, 77, $185-268$.

3. Singh, A.K.; Bhatt, B.P.; Upadhya, A.; Singh, B.K.; Kumar, S.; Sundaram, P.K.; Chndra, N.; Bharati, R.C. Improvement of faba bean (Vicia faba L.) yield and quality through biotechnological approach: A review. Afr. J. Biotechnol. 2012, 11, 15264-15271. 
4. Zeidan, M.S.; Hozayn, M.; Abd El-Salam, M.E.E. Yield and Quality of Lentil as Affected by Micronutrient Deficiencies in Sandy Soils. J. Appl. Sci. Res. 2006, 2, 1342-1345.

5. Deo, K.; Singh, S.B. Effect of Zinc and Boron application on Yield of Lentil and Nutrient Balance in the Soil under Indo-Gangetic Plain Zones. J. AgriSearch 2014, 1, 206-209.

6. Singh, S.S.; Singh, A.K.; Sundaram, P.K. Agrotechnological options for upscaling agricultural productivity in eastern indo gangetic plains under impending climate change situations: A review. J. AgriSearch 2014, 1,55-65.

7. Khan, H.R.; McDonald, G.K.; Rengel, Z. Zinc fertilization and water stress affects plant water relations, stomatal conductance and osmotic adjustment in chickpea (Cicer arietinum). Plant Soil 2004, 267, 271-284. [CrossRef]

8. Ahlawat, I.P.S.; Gangaiah, B.; Ashraf Zadid, M. Nutrient management in chickpea. In Chickpea Breeding and Management; Yadav, S.S., Redden, R., Chen, W., Sharma, B., Eds.; CAB International: Wallingford, UK, 2007; pp. 213-232.

9. Hamilton, M.A.; Westermann, D.T.; James, D.W. Factors affecting zinc uptake in cropping systems. Soil Sci. Soc. Am. J. 1993, 57, 1310-1315. [CrossRef]

10. Singh, M.; Ram, N. Effect of soil enrichment with zinc on crop yields and its replenishment in Mollisols of northern India. Agrochimica 1996, 40, 19-24.

11. Singh, A.K.; Khan, M.A.; Srivastava, A. Effect of boron and molybdenum application on seed yield of mungbean. Asian J. Biol. Sci. 2014, 9, 169-172. [CrossRef]

12. Subasinghe, S.; Dayatilake, G.A.; Senaratne, R. Effect of B, Co and Mo on nodulation, growth and yield of cowpea (Vigna unguiculata). Trop. Agric. Res. Ext. 2003, 6, 108-112.

13. Hansch, R.; Mendel, R.R. Physiological functions of mineral micronutrients (Cu, Zn, Mn, Fe, Ni, Mo, B, Cl). Curr. Opin. Plant Biol. 2009, 12, 259-266. [CrossRef] [PubMed]

14. Chakraborty, A. Growth and yield of lentil (Lens culinaris L.) as affected by Boron and Molybdenum application in lateritic soil. J. Crop Weed 2009, 5, 88-91.

15. Chatterjee, R.; Bandyopadhyay, S. Effect of boron, molybdenum and biofertilizers on growth and yield of cowpea (Vigna unguiculata L. Walp.) in acid soil of eastern Himalayan region. J. Saudi Soc. Agric. Sci. 2017, 16, 332-336. [CrossRef]

16. Valenciano, J.B.; Marcelo, V.; Boto, J.A. Response of chickpea (Cicer arietinum) yield to micronutrient application under pot conditions in Spain. Span. J. Agric. Res. 2010, 8, 797-807. [CrossRef]

17. Quddus, M.A.; Mian, M.J.A.; Naser, H.M.; Hossain, M.A.; Sultana, S. Maximizing Yields, Nutrient Uptake and Balance for Mustard-Mungbean-T. Aman Rice Cropping Systems through Nutrient Management Practices in Calcareous Soils. J. Agric. Sci. 2017, 9, 210-229. [CrossRef]

18. Birru, A. Agricultural Field Experiment Management Manual Part III; IAR (Institute of Agricultural Research): Addis Ababa, Ethiopia, 1979; pp. 35-42.

19. Food and Agriculture Origination Publication (FAO). Manuals of Food Quality Control, Food Analysis: General Techniques Additives, Contaminants, and Composition; FAO Food and Nutrition Paper 14/7; Centre for Food Safety, UN: Rome, Italy, 1986.

20. Piper, C.S. Soil and Plant Analysis; Hans Publishers: Bombay, India, 1966; pp. 368-392.

21. Bremner, J.M.; Mulvaney, C.S. Total nitrogen. In Methods of Soil Analysis, Part 2, Chemical and Microbiological Properties; Page, A.L., Miller, R.H., Keeny, D.R., Eds.; American Society of Agronomy: Madison, WI, USA; Soil Science Society of America, Inc.: Madison, WI, USA, 1982; pp. 595-624.

22. Olsen, S.R.; Sommers, L.E. Phosphorus. In Methods of Soil Analysis, Part 2, Chemical and Microbiological Properties; Page, A.L., Miller, R.H., Keeny, D.R., Eds.; American Society of Agronomy Inc.: Madison, WI, USA, 1982; pp. 403-430.

23. Page, A.L.; Miller, R.H.; Kuny, D.R. Methods of Soil Analysis. Part 2. Chemical and Microbiological Properties, 2nd ed.; American Society of Agronomy, Inc.: Madison, WI, USA; Soil Science Society of American Inc.: Madison, WI, USA, 1982.

24. Black, C.A. Methods of Soil Analysis Part-II; American Society of Agronomy, Inc.: Madison, WI, USA, 1965; p. 770.

25. Piper, G.S. Soil and Plant Analysis; Adelaide University, Hassell Press: Adelaide, Australia, 1950. 
26. Barker, D.E.; Surh, N.H. Atomic Absorption and Flame Emission Spectroscopy. In Methods of Soil Analysis. Part 2: Chemical and Microbiological Properties, 2nd ed.; Page, A.L., Miller, R.H., Keeny, D.R., Eds.; SSSA Book Series No. 9; SSSA: Madison, WI, USA; ASA: Madison, WI, USA, 1982; pp. 13-26.

27. Gomez, K.A.; Gomez, A.A. Statistical Procedure for Agricultural Research; John Willey and Sons: New York, NY, USA, 1984.

28. Singh, A.; Singh, B.B.; Patel, C.S. Response of vegetable pea (Pisum sativum) to zinc, boron and molybdenum in an acidi Alsifol of Meghalaya. Indian J. Agron. 1992, 37, 615-616.

29. Basavrajeswari, C.P.; Hosamani, R.M.; Ajjappalavara, P.S.; Naik, B.H.; Smitha, R.P.; Ukkund, K.C. Effect of foliar application of micronutrients on growth, yield components of Tomato (Lycopersicon esculentum Mill.). Karnataka J. Agric. Sci. 2008, 21, 428-430.

30. Sharma, S.K. Effect of boron and calcium on seed production of Bell pepper (Capsicum annuum L.). Veg. Sci. 1999, 26, 87-88.

31. Kiran, J.V.; Yakaranchal, B.S.; Raikar, S.D.; Ravikumar, G.H.; Deshpande, V.K. Seed yield and quality of brinjal as influenced by crop nutrition. Indian J. Agric. Res. 2010, 44, 1-7.

32. Mohanty, S.K.; Sahoo, L.P.; Dash, S. Effect of bio-fertilizer and micronutrients on vegetative and reproductive growth behaviour and seed yield in tomato. In Proceedings of the XII National Seed Seminar, UAS Bengaluru, Bengaluru, India, 8-10 June 2013; Abstracts. p. 41.

33. Hatwar, G.P.; Gondane, S.M.; Urkade, S.M.; Ahukar, O.V. Effect of micronutrients on growth and yield of chilli. Soils Crops 2003, 13, 123-125.

34. Bhatia, V.S.; Singh, B.N.; Lal, S. Variability and interrelationship of yield and its attributes in chickpea. Indian J. Pulses Res. 1993, 6, 1-5.

35. Taliee, A.; Sayadian, K. Effect of supplemental irrigation and plant nutrient in chickpea (dry farming). J. Agron. Crop Sci. 2000, 2, 12-19.

36. Nadergoli, M.S.; Yarnia, M.; Khoei, F.R. Effect of zinc and manganese and their application method on yield and yield components of common bean. Middle-East J. Sci. Res. 2011, 8, 859-865.

37. Quddus, M.A.; Rashhid, M.H.; Hossain, M.A.; Naser, H.M. Effect of zinc and boron on yield and yield contributing characters of mungbean in low ganges river floodplain soil at madaripur, Bangladesh. Bangladesh J. Agric. Res. 2011, 36, 75-85. [CrossRef]

38. Valenciano, J.B.; Boto, J.A.; Marcelo, V. Chickpea (Cicer arietinum L.) response to zinc, boron and molybdenum application under field conditions. N. Z. J. Crop Hortic. Sci. 2011, 39, 217-229. [CrossRef]

39. Begum, R. Effect of Some Micronutrients Application on Seed Yield and Quality in Green Gram. Master's Thesis, Orissa University of Agriculture and Technology, Bhubaneswar, Odisha, India, 2014.

40. Nasir, M.; Khalatbari, M.; Farahani, H.M. Zn-foliar application influence on quality and quality features in Phaseolus vulgaris under different levels of $\mathrm{N}$ and K fertilizers. Adv. Environ. Biol. 2011, 5, 839-846.

41. Dordas, C.; Apostolides, G.E.; Goundra, O. Boron application affects seed yield and seed quality of sugar beets. J. Agric. Sci. 2007, 145, 377-384. [CrossRef]

42. Ramu, Y.R.; Reddy, D.S. Effect of micronutrient management on growth, yield, quality and economics of hybrid maize. Crop Res. 2007, 33, 46-49.

43. Punia, R.C.; Dahiya, O.S.; Jakhar, S.S. Effect of micronutrients on seed yield and quality in wheat. In Proceedings of the XII National Seed Seminar, UAS Bengaluru, Bengaluru, India, 8-10 June 2013; Abstracts, p. 75.

44. Yang, M.; Shi, L.; Xu, F.S.; Lu, J.W.; Wang, Y.H. Effects of B, Mo, Zn and their interactions on seed yield of rapeseed. Pedosphere 2009, 19, 53-59. [CrossRef]

45. Jain, G.L. Secondary and micronutrients in relation to 'mothbean' (Phaseolus aconitifolius Jacq.). Effect of soil application on uptake and fixation of N. Indian J. Agron. 1973, 18, 517-519.

46. Barik, T.; Rout, D. Effect of foliar spray of commercial micronutrient mixtures on growth, yield and quality of urdbean. Legum. Res. 1990, 13, 50-62.

47. Rosolem, C.A.; Caires, E.F. Yield and nitrogen uptake of peanuts as affected by lime, cobalt and molybdenum. J. Plant Nutr. 1998, 21, 827-835. [CrossRef]

48. O'Hara, G.W. Nutritional constraints on root nodule bacteria affecting symbiotic nitrogen fixation: A review. Aust. J. Exp. Agric. 2001, 41, 417-433. [CrossRef]

49. Bolanos, L.; Brewin, N.J.; Bonilla, I. Effects of boron on Rhizobium-legume cell-surface interactions and nodule development. Plant Physiol. 1996, 110, 1249-1256. [CrossRef] [PubMed] 
50. Allen, R.M.; Roll, J.T.; Rangaraj, P.; Shah, V.K.; Roberts, G.P.; Ludden, P.W. Incorporation of molybdenum into the iron-molybdenum cofactor of nitrogenase. J. Biol. Chem. 1999, 274, 15869-15874. [CrossRef] [PubMed]

51. Franco, A.A.; Munns, D.N. Response of Phaseolus vulgaris L. to molybdenum under acid conditions. Soil Sci. Soc. Am. J. 1981, 45, 1144-1148. [CrossRef]

52. Vieira, R.F.; Cardoso, E.J.B.N.; Vieira, C.; Cassini, S.T.A. Foliar application of molybdenum in common beans. I. Nitrogenase and reductase activities in a soil of high fertility. J. Plant Nutr. 1998, 21, 169-180. [CrossRef]

53. Yanni, Y.G. Performance of chickpea, lentil and lupin nodulated with indigenous or inoculated rhizobia micropartners under nitrogen, boron, cobalt and molybdenum fertilization schedules. World J. Microbiol. Biotechnol. 1992, 8, 607-613. [CrossRef] [PubMed]

54. Hossain, M.B.; Kumar, T.N.; Ahmed, S. Effect of Zinc, Boron and Molybdenum application on the yield and nutrient uptake by BRRI Dhan 30. Online J. Biol. Sci. 2001, 1, 698-700.

55. Sarker, S.K.; Chowdhury, M.A.H.; Zakir, H.M. Sulphur and boron fertilization on yield quality and nutrient uptake by Bangladesh Soybean-4. Online J. Biol. Sci. 2002, 2, 729-733.

56. Okaz, A.M.A.; El-Gareib, E.A.; Kadry, W.; Negm, A.Y.; Zahran, F.A.F. Micronutrient application to lentil plants grown on newly reclaimed sandy soils. Proceedings of 6th Conference of Agronomy, Al-Azhar University, Cairo, Egypt, 2-4 September 1994; Volume II, pp. 737-752.

57. Singh, A.K.; Meena, M.K.; Bharati, R.C.; Gade, R.M. Effect of sulphur and zinc management on yield, nutrient uptake, changes in soil fertility and economics in rice (Oryza sativa)-lentil (Lens culinaris) cropping system. Indian J. Agric. Sci. 2013, 83, 344-348.

58. Iqtidar, A.; Rahman, S.F. Effect of boron on the protein and amino acid composition of wheat grain. J. Agric. Sci. 1984, 103, 75-80. [CrossRef]

59. Ogbodo, E.N. Effect of crop residue on soil chemical properties and rice yield on an Ultisol at Abakaliki, Southeastern Nigeria. World J. Agric. Sci. 2011, 7, 13-18.

60. Hinsinger, P. How do plant roots acquire mineral nutrients? Chemical processes involved in the rhizosphere. Adv. Agron. 1998, 64, 225-265.

61. Hinsinger, P. Bioavailability of soil inorganic $\mathrm{P}$ in the rhizosphere as affected by root-induced chemical changes: A review. Plant Soil 2001, 237, 173-195. [CrossRef]

62. Hinsinger, P. Origins of root-mediated $\mathrm{pH}$ changes in the rhizosphere and their responses to environmental constraints: A review. Plant Soil 2003, 248, 43-50. [CrossRef]

63. Ahlawat, I.P.S.; Srivastava, T.K. Fertility management in pulse based cropping systems. In Recent Advances in Pulses Research; Asthana, A.N., Masood, A., Eds.; Indian Society of Pulses Research and Development: Kanpur, India, 1997; pp. 509-523.

64. Rao, J.V.; Bhardwaj, R.B.L. Influence of residual fertility on green gram in intensive cropping system. Indian J. Agron. 1980, 25, 97-101.

65. Singh, S.K.; Varma, S.C.; Singh, R.P. Economics and nutrient uptake in Rice-Lentil cropping sequence. Agric. Sci. Dig. 2003, 23, 122-124.

(C) 2018 by the authors. Licensee MDPI, Basel, Switzerland. This article is an open access article distributed under the terms and conditions of the Creative Commons Attribution (CC BY) license (http://creativecommons.org/licenses/by/4.0/). 